\title{
Validation of the cone penetrometer suitability for determining the state of soil
}

\author{
M. MAŚLAKOWSKI ${ }^{1}$, K. BRZEZIŃSKI ${ }^{2}$, A. ZBICIAK ${ }^{3}$, K. JÓZEFIAK ${ }^{4}$
}

The subject matter of this paper is assessment of the suitability of a dynamic cone penetrometer for determination of the state of soil. The principle of operation of the dynamic cone penetrometer, similar to commonly used DPL penetrometers, is described in the paper. Next the results of investigation conducted in Poland using a new dynamic cone penetrometer are presented. A series of measurements were performed in real field conditions. An attempt was made to correlate the results obtained with the dynamic and static cone penetrometers (CPT) respectively. These correlations were then subjected to validation to obtain a preliminary evaluation of the suitability of the dynamic cone penetrometer for determining the state of soil.

Keywords: dynamic cone penetrometer, CPT static cone penetrometer, in-situ methods, state of soil, correlation,

\section{INTRODUCTION}

\footnotetext{
${ }^{1} \mathrm{PhD}$., Warsaw University of Technology, Faculty of Civil Engineering, Kaczyńskiego16, 00-637 Warsaw, Poland, e-mail: m.maslakowski@il.pw.edu.pl

${ }^{2} \mathrm{PhD}$., Eng., Warsaw University of Technology, Faculty of Civil Engineering, Kaczyńskiego 16, 00-637 Warsaw, Poland, e-mail: k.brzezinski@il.pw.edu.pl

${ }^{3}$ DSc., PhD., Eng., Warsaw University of Technology, Faculty of Civil Engineering, Kaczyńskiego 16, 00-637 Warsaw, Poland, e-mail: a.zbiciak@il.pw.edu.pl

${ }^{4}$ MSc.., Eng., Warsaw University of Technology, Faculty of Civil Engineering, Kaczyńskiego16, 00-637 Warsaw, Poland, e-mail: k.jozefiak@il.pw.edu.pl
} 
There are various, more or less popular methods used to determine the state of soil by $i$-situ field testing, such as dynamic methods (DPL and DPSH) or static probing methods (e. g. SPT, SLVT).

There are new test rigs appearing in the Polish market which, while used with success in Western European countries and in other parts of the world, are still not widely known in Poland.

It is worth getting familiar with them and thus extend the array of available tools for evaluating the state of soil. An example of such new test rigs is PANDA 2. It combines the dynamic and static characteristics of the above-mentioned types of probing.

PANDA 2 was already described in one of its applications, namely determination of the mechanical properties of soil, such as E-modulus or cohesion [1,2]. Owing to a relatively small weight resulting in its high mobility the rig can be successfully used for testing the compaction of soil in constrained places, such as dams [3], slopes [4] and railway subgrades [5].

Comparisons with other geotechnical in-situ field testing systems have also been done, including dynamic plate [6] or dynamic probe [7] systems.

This paper evaluates the suitability of the dynamic cone penetrometer for determining the state of soil, and presents the results of this evaluation. The principle of operation of the system under analysis is described (note similarity to operation of commonly used lightweight penetrometer DPL). It is followed by presentation of results of tests carried out in Poland with the use of PANDA 2 dynamic cone penetrometer. These results were used for preliminary evaluation of the suitability of dynamic cone penetrometer for soil state determination. 


\section{Description Of The Test Procedures}

\subsection{LOCAL CONDITIONS, LITHOLOGY}

The tests of this research were carried out in the central part of Warsaw. In geomorphological terms the area is located in the upper portion of the Vistula floodplain, elevated ca. $5 \mathrm{~m}$ above the chart datum of the Vistula. Poorly draining soils are found there, including silty clay, sandy silt, which are, by origin, alluvial deposits, underlain with sandy permeable deposits - see Fig. 1.

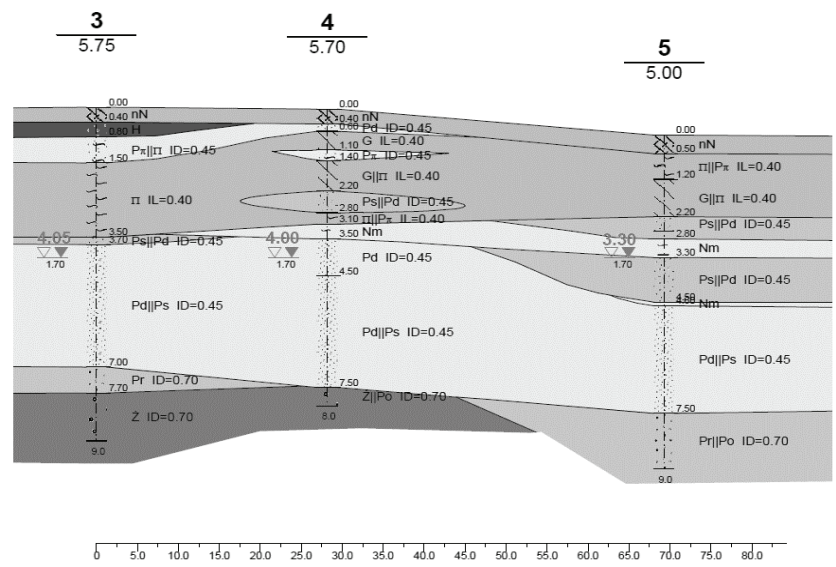

Fig. 1 Example geological transect in the area of research

The value of $\mathrm{I}_{\mathrm{L}}=0.40-0.45$ obtained for cohesive soils classifies them in the plastic state and the value of $\mathrm{I}_{\mathrm{D}}=0.45$ obtained for loose soils classifies them in the medium-compact state.

Moreover, at the depth range of ca. 3.3-4.0 m BGL ground water table was encountered.

\subsection{DESCRIPTION OF THE TESTS}

Two test methods were used for further correlative analysis and validation:

- electric cone penetration test

- PANDA 2 dynamic cone penetrometer test - Fig. 2. 


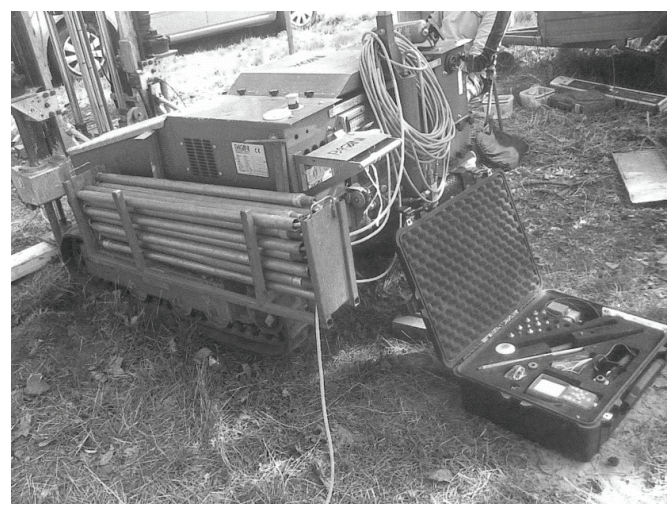

Fig. 2. CPTU test rig and Panda 2 prepared for testing

The layout of the test points is presented schematically in Fig. 3.

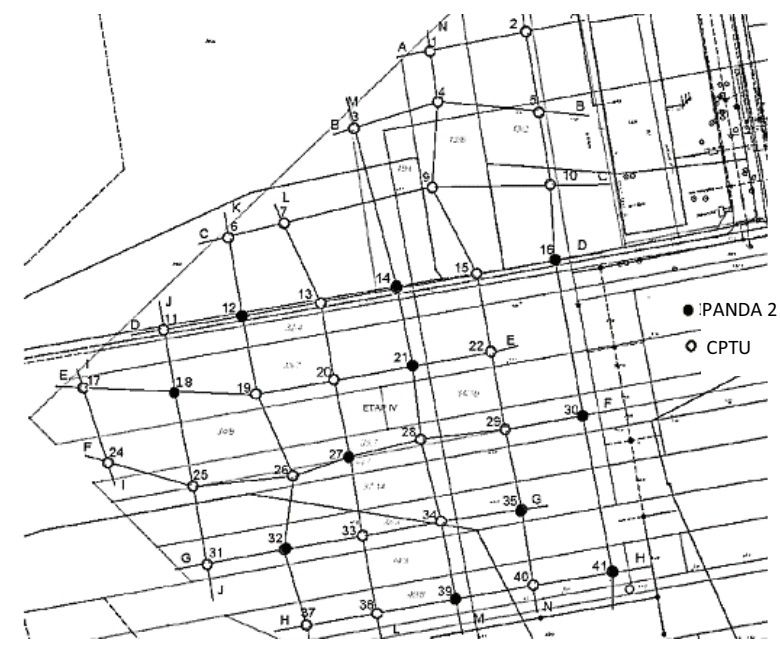

Fig. 3. Schematic layout of the test points

Since CPT is a widely used method, its description has been purposefully omitted, the purpose being to give readers an insight into a less known method using the PANDA 2 dynamic cone penetrometer.

PANDA 2 is a system manufactured in France and commonly used throughout the world for testing various soil parameters. The system description and its principle of operation have been defined by the French Standard XP P 94-105 [8]. The complete PANDA 2 test rig is presented Fig. 4. 


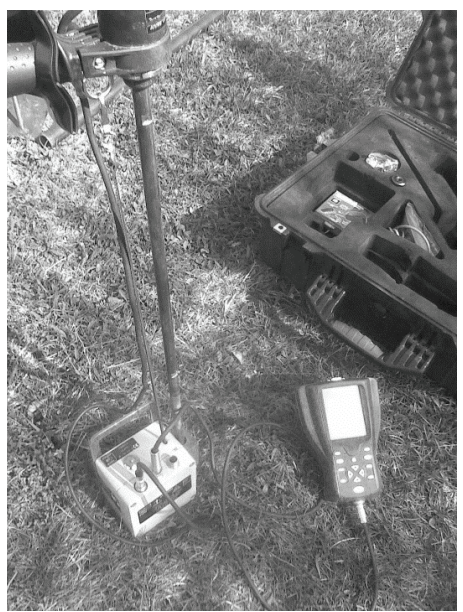

Fig. 4. Panda 2 test rig prepared for testing

The main components of the systems are:

- a set of cones driven in soil of $2 \mathrm{~cm}, 4 \mathrm{~cm}$ and $10 \mathrm{~cm}$ in diameter

- a set of ten $0.5 \mathrm{~m}$ long drive rods providing up to $5 \mathrm{~m}$ penetration depth range, ended with an anvil and holder, used to transmit blow energy,

- measuring system comprising the device measuring the penetration depth and the data acquisition unit. In the tests carried out to establish correlation with CPT results lost cones of $4 \mathrm{~cm}$ in diameter were used, in accordance with the manufacturer's recommendations.

The dynamic cone penetrometer is operated similarly to other dynamic probing systems commonly used in Poland. In the test, variable amounts of energy are delivered to the system by hammer impacting the anvil which forms an integral system with the set of rods equipped with the penetrating tip. With each stroke the unit measures energy delivered to the system in the direction of penetration and also the penetration depth of driving rod tipped with a cone - Fig. 5. 


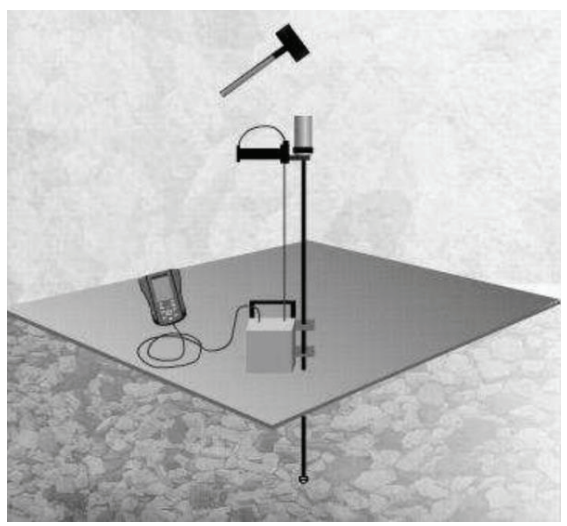

Fig. 5. Schematic of PANDA 2 operation. [9]

The dynamic cone resistance is calculated with the Dutch formula, as defined in the French Standard XP P 94$105[8]$.

$$
q=E^{*} M /\left[A^{*} e^{*}(M+P)\right]
$$

where:

$q$ - dynamic cone resistance [MPa]

$E$ - energy input per blow $[\mathrm{J}]$

$A$ - area of the cone $\left[\mathrm{m}^{2}\right]$

$e^{\prime}-$ penetration depth $[\mathrm{m}]$

$M$ - weight of the hammer $[\mathrm{kg}]$

$P$ - weight of anvil and rod assembly $[\mathrm{kg}]$

The main parameters obtained in the tests are: energy transferred with each blow, cone resistance and penetration of the rod mounted on the tip of the driving (guide) rod - Fig. 6 . 

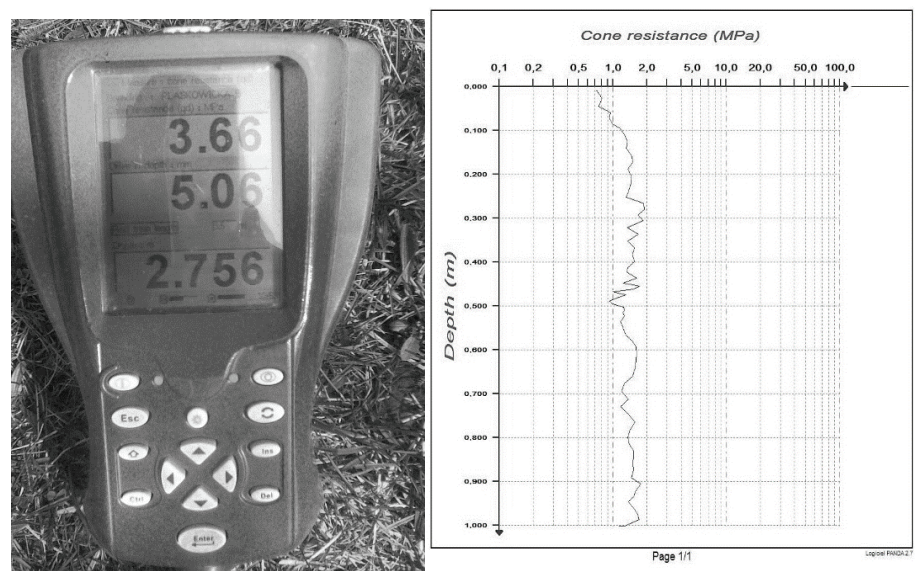

Fig. 6 Example readouts recorded by the data acquisition unit (from the top: energy given to the system with each blow, cone resistance and cone penetration) and example chart of complete test carried out with PANDA 2 system.

\section{ANAlysis Of THE TeSt Results}

\subsection{RELATIONSHIP BETWEEN THE MEASURED RESISTANCE VALUES}

Due to different methods of measurements the rough data from the dynamic and static tests have different formats. In CPT apparatus the cone is driven continuously. In practice, the readings are regularly discretized, for example at $2 \mathrm{~cm}$ intervals. Conversely, in the tests performed with Panda 2 the penetration depth varies between blows depending on the state of soil and on the applied force. Therefore, before further analysis, the results at each point were averaged per $20 \mathrm{~cm}$ long sections.

A comparative analysis of the results obtained in the CPT and dynamic penetrometer tests can be performed in two ways. Firstly, there are certain correlation relationships, which are used to estimate the mechanical parameters of soils on the basis of the test results. It is thus possible to compare the parameters derived in this way. The second method compares only the cone resistance values obtained with the two systems. It starts by deriving a correlation relationship between cone resistances which is subjected to validation as the next step. A clear relationship, which can be figured out from Fig. 7, was observed in many cases on the basis of comparative analysis of cone resistances at different locations (test points). There are also points for which such a clear correlation cannot be found (Fig. 8). 


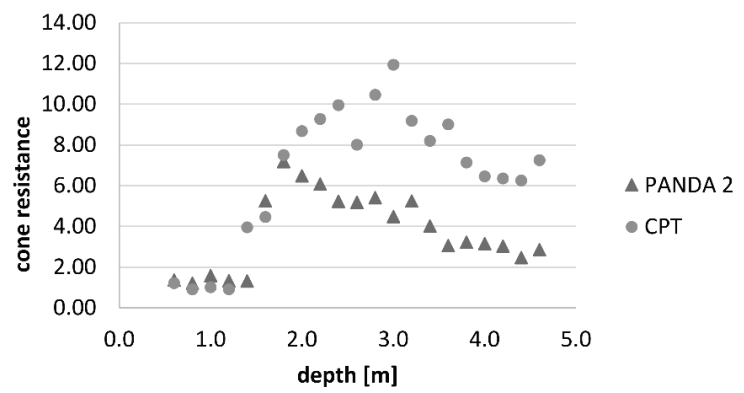

Fig. 7. Cone resistances obtained with different probes, depending on the penetration depth (test point No.

11)

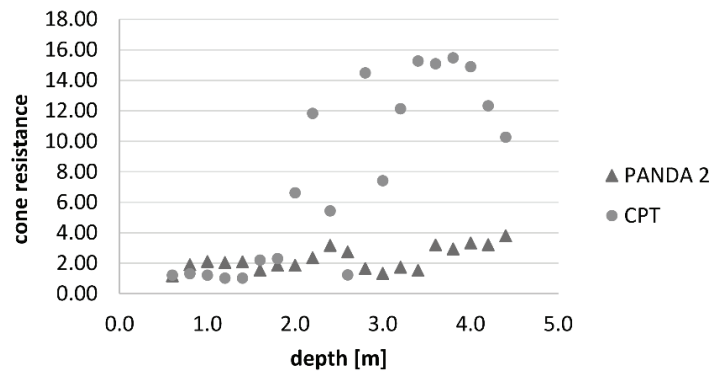

Fig. 8. Cone resistances obtained with different probes, depending on the penetration depth (test point No. 2)

Moreover, a higher consistency between the results can be seen for penetration depths up to ca. $2 \mathrm{~m}$. It is, however, not known which of the following are responsible for that: type of soil, penetration depth or small measured resistance. Our lithological analysis has not answered the question why in some points the cone resistances exhibit correlation between the dynamic cone penetrometer and CPT tests while in other such clear relationship cannot be established. For this reason, no points have been excluded from further analyses. A relatively good accuracy can be expected, yet at the present moment we must take into account some uncontrollable factors which can affect it in certain conditions. Based on the above observation, we can increase the accuracy by limiting the range of analysis to the maximum depth of $2.0 \mathrm{~m}$, where a much higher consistency between the cone resistance values is obtained.

Finally, in order to obtain correlation relationship the results from all the test points were used. The simplest relationship represented by the straight line of best fit, as presented in Fig. 9, explains $47 \%$ of the variability of results. 


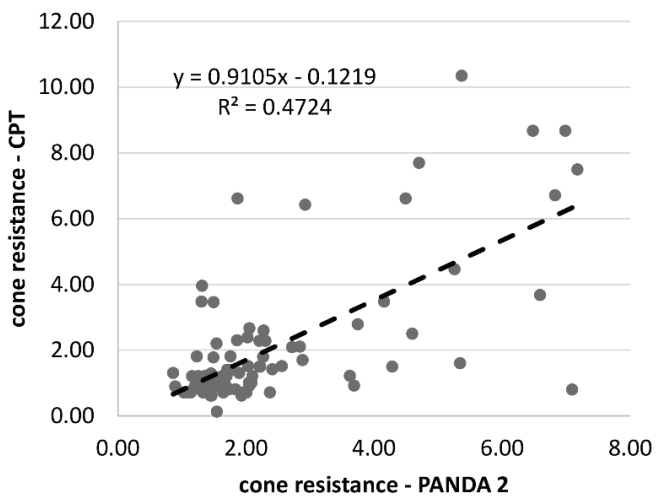

Fig. 9. Relationship between resistances obtained with different test rigs

In our earlier articles concerning validation $[10,11,12]$, we stressed that popularising the correlative relationship as an equation only will result in losing information on the uncertainty of results. For this reason, validation was conducted as the next step, to evaluate the applicability of the obtained equation.

\subsection{VALIDATION OF THE OBTAINED RELATIONSHIPS}

According to the methodology described in [12] validation consisted in determining the width of confidence interval for a single result. The objective is to obtain a relationship which can be used to convert any individual result to another individual result: cone resistance of dynamic penetrometer to CPT cone resistance. The confidence interval is the range in which the result should fall at a specific probability ( $90 \%$ probability is assumed for the purposes hereof). With the confidence interval superimposed on the diagram representing the correlation formula it is much easier to evaluate the method applicability since we know what degree of accuracy can be expected.

The methodology adopted by us requires that the error (residuals) is independent of the correlation function's independent variable. The residuals chart is presented in Fig. 10. 


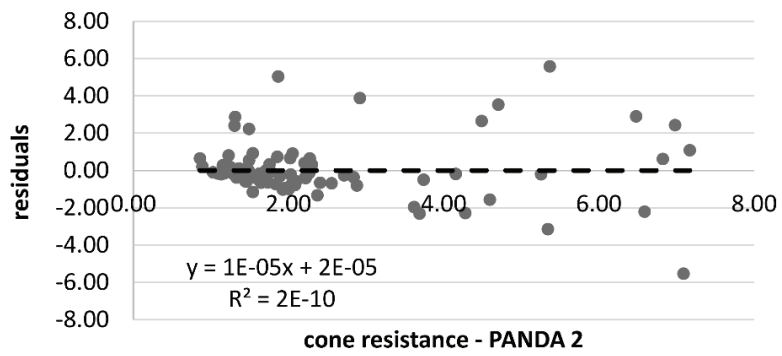

Fig. 10 Residuals chart of a linear correlation function

As we can see, the values actually oscillate around zero without any apparent tendency, yet for smaller resistance values the dispersion is much smaller than for bigger ones.

Hence, another attempt was made to find correlation - this time after taking logarithms of the cone resistance values on both axes. The result of correlation in the log-log plane is presented in Fig. 11 and the residuals of the new correlative formula are plotted in the chart in Fig. 12.

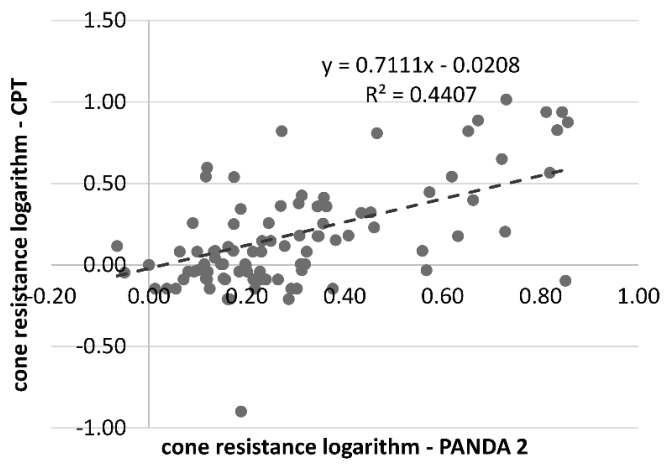

Fig. 11. Relationship between resistances obtained with different test rigs in the log-log plane 


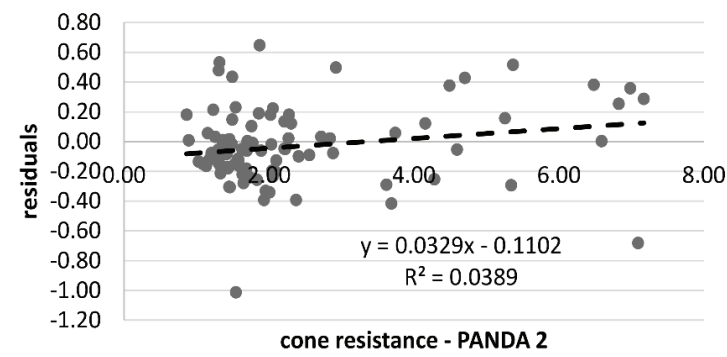

Fig. 12 Residuals chart of the logarithmic correlation function

As it can be seen, correlation of a similar strength was obtained. Conversely, a small increasing trend appeared in the case of residuals, yet with a more uniform dispersion of the data.

When these results are fed again in the system defined by non-logarithmised cone resistances, the chart we obtain is no longer linear (Fig. 13).

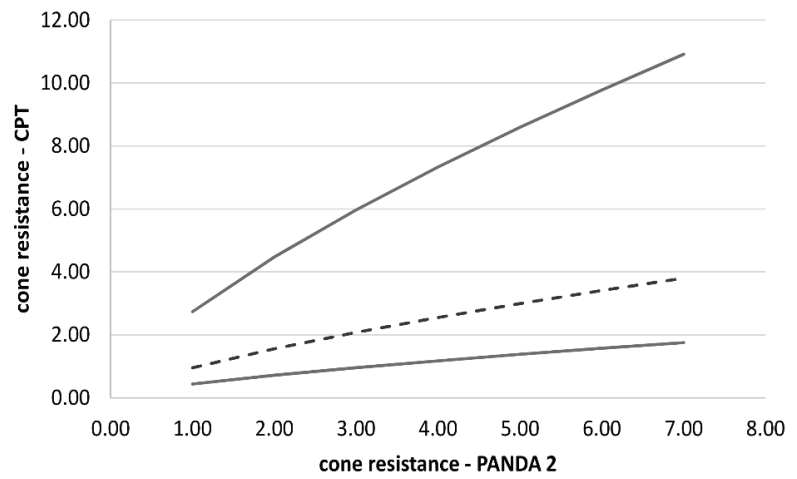

Fig. 13 Relationship between cone resistances obtained with different test rigs (dotted line - mean, continuous line - confidence interval)

Similarly curved are also the confidence interval limits represented by the continuous lines. A $90 \%$ confidence interval was adopted which, as it can be seen, expands with the increase of the measured cone resistance of PANDA 2 test rig. The results should be interpreted as described below. For the measured cone resistance value of $1 \mathrm{MPa}$ we can expect, with a probability of $90 \%$ that the CPT result will fall in the 1-3 MPa range, i.e. the width of the confidence interval is ca. $2 \mathrm{MPa}$. For $7 \mathrm{MPa}$ cone resistance obtained with the PANDA test rig we expect results in the range from 2 to $11 \mathrm{MPa}$. They will oscillate around the expected value of 4 MPa. 
The reason the confidence interval expands is that it was originally plotted as two parallel lines in a log-log plane and then we have got back to a non-transformed space. In practice the searched values of parameters are often derived on the basis of a logarithm of the measured cone resistance. Hence an increase of uncertainty at higher cone resistance values does not necessarily translate to a higher uncertainty of the derived parameter. It should be emphasized that test was conducted in single location in Poland. Generalization of the correlation formulas for other regions usually results in decrease of its accuracy. So all the conclusions drawn, should be interpreted as conclusion of applicability of the method, when local calibration is taken into account.

\subsection{VALIDATION ON THE BASIS OF THE DERIVED PARAMETERS}

The next element of the analysis is evaluation of the suitability of the dynamic cone penetrometer for estimating the derived values of soil parameters.

Since up to $2 \mathrm{~m}$ depth the soil is built generally of cohesive material, the parameter chosen for analysis was liquidity index $I_{L}$.Using the cone resistances $\left(q_{c}\right)$ measured with the two rigs the liquidity index was calculated with the same equation [14]:

$$
I_{L}=0.729-0.7367 * \log \left(q_{c}\right)
$$

The differences between the liquidity index values obtained with the validated method and with the reference method were calculated and analysed as the next step. For the sake of simplicity it is assumed that the cone resistance values were obtained with the respective test methods at locations close enough to treat the medium as uniform and, as such, we can attribute the variation of results to different testing methods rather than to the variation in the soil medium. The distribution of these differences is used to determine the limits of the confidence interval. CPT was taken as the reference method due to its greater popularity and more experience in its application.

The confidence interval width depends on the standard deviation value which represents the scatter of results. The interval in question was constructed using the T-student distribution. It is used when the precise value of the standard deviation of the population is unknown. A prerequisite to its applicability is normality of the differences between the results obtained with the reference and the validated methods. Shapiro-Wilk normality test was conducted to demonstrate that such assumption can be made [13].

The following limits were obtained for the $90 \%$ confidence interval with the above described methodology:

- -0.099 (lower limit),

- 0.320 (upper limit).

Thus, for a given liquidity index value obtained with PANDA 2 rig (for example 0.50 ) one can expect, that the value obtained with the CPT method would fall, with a probability of $90 \%$, in the range of $0.40-0.82$. The 
confidence interval width of ca. 0.4 indicates a relatively big scatter. Note, however, that the two methods used to derive the compared parameters are approximate, and, besides, each of them has some inaccuracy. Further analyses should be carried out to verify the results by comparing those derived from the dynamic cone penetrometer with those calculated on the basis of laboratory test results.

\section{DISCUSSION}

The following conclusions are drawn from this study:

- The method described in this paper has got a lot of potential and requires further research to explain the discrepancies of results at certain test points. These discrepancies translate to uncertainty of results since the analysis covers the data from all the test points.

- In the case of a direct relationship between the cone resistances obtained with CPT and PANDA 2 test rigs attention is drawn to an increase of error with the increase of the depth and the measured resistance value.

- Applicability of the method is defined also by the accuracy of the derived soil parameters. Liquidity index, chosen as an example parameter of soil, exhibited a relatively big dispersion (ca. 0.4 width of $90 \%$ confidence interval). Moreover, validation with the use of a more accurate method (laboratory testing) should also be carried out.

- The applicability of the method depends on the desired accuracy (it is different at the conceptual stage as compared to the planning approval stage of the design process). Therefore, we can leave it up to the designer to decide about the method's applicability if its accuracy is known. For this reason, information on the uncertainty of results (expressed for example by the confidence interval) should be publicised together with correlation formulas.

Even with a small depth of investigation the method can have numerous applications. The mechanisticempirical method used for designing pavements requires investigation of the subgrade to $2 \mathrm{~m}$ depth below the bottom of the pavement structure. Owing to its simplicity and a small input of labour the method described in this paper can be used not only at the design stage but also for evaluation of the existing pavements and in research projects. For example, regular testing of subgrade would provide a more robust evaluation of the seasonal variations of its parameters. When such testing is accompanied with, for example, the data concerning the pavement courses [15] and deflection measurements and analysis [16] it can lead to obtaining more accurate methods for predicting the service life of road pavements.

The method can also be used for estimating cohesion and internal friction angle of soil. Their values can be used in elastic-plastic analyses of structures. However, with the input data limited to these parameters only Mohr-Coulomb model, i.e. the simplest one can be used. Nevertheless, as demonstrated in [17] this model can in many situations provide results that are consistent with the field data. 


\section{REFERENCES:}

1. Navarrete M. A. B., Gourvès R., Haddani Y., Détermination de paramètres dynamiques du sol lors du battage pénétromètrique par découplage d'ondes, 8ème Colloque National AFPS 2011.

2. Benz M. A. , Escobar E., Gourvès R., Haddani Y., Mesures dynamiques lors du battage pénétromètrique Détermination de la courbe charge-enfoncement dynamique en pointe, Proceedings of the 18th International Conference on Soil Mechanics and Geotechnical Engineering, Paris 2013r.

3. Villavicencio G., Breul P., Bacconnet C., Boissier D., Espinace R., Estimation of the Variability of Tailings Dams Properties in Order to Perform Probabilistic Assessment, Geotechnical and Geological Engineering, An International Journal ISSN 0960-3182, 2006. DOI: 10.1007/s10706-011-9438-5

4. Athapaththu A.M.R.G., Tsuchida T., Assessment of natural slopes susceptible to failure in heavy rainfall based on in-situ cone resistance data, Japanese Geotechnical Society Special Publication The 15th Asian Regional Conference on Soil Mechanics and Geotechnical Engineering. 2016. DOI: 10.3208/jgssp.JPN-027

5. Haddani Y., Breul P, Saussine G., Navarrete M. A. B., Ranvier F and Gourvèsn R., Trackbed Mechanical and Physical Characterization using PANDA ${ }^{\circ}$, Geoendoscopy Coupling Procedia Engineering Volume 143, 2016, pages 1201-1209, DOI: 10.1016/j.proeng.2016.06.118

6. Herrera F., Espinace R., Palma Y., Innovative Technologies for the Control of Soil Compaction: Review of the State of the Art. And Experiences in Chile, From Fundamentals to Applications in Geotechnics D. Manzanal and A.O. Sfriso (Eds.) IOS Press, 2015. DOI: 10.3233/978-1-61499-603-3-63

7. Khodaparast M., Rajabi A.M., Mohammadi M., The new empirical formula based on dynamic probing test results in fine cohesive soils, International Journal of Civil Engineering, Vol. 13, No. 2, Transaction B: Geotechnical Engineering, June 2015. DOI: 10.22068/IJCE.13.2.105

8. XP P94 105 French Std for Compaction Quality - Insitu Test. Méthode au pénétromètre dynamique à énergie variable - Principe et méthode d'étalonnage du pénétromètre - Exploitation des résultats - Interprétation.

9. Manual - Dynamic Cone Penetrometer PANDA, Compaction Control Soil Investigation, Sol Solution 2010.

10. Brzeziński K., Maślakowski M., Sokołowska M., Preliminary validation of the dynamic probing methods used in estimation of the relative density of cohesionless soils., MATEC Web of Conferences. Vol. 117. EDP Sciences article number 00024, 2017. DOI: 10.1051/matecconf/201711700024

11. Brzeziński K., Maślakowski M., Zbiciak A., Józefiak K., Koncepcja procedury walidacji metod rozpoznania podłoża gruntowego $\mathrm{w}$ drogownictwie [The concept of validation procedure for subgrade diagnostic tools in road engineering], Drogownictwo: 85-91, 2017. (in Polish)

12. Brzeziński K., Tutka P., Maślakowski M., Wybrane zagadnienia walidacji metod rozpoznania podłoża gruntowego [Certain issues of the subsoil recognition methods validation], TTS Technika Transportu Szynowego 12, 2017. (in Polish with English summary)

13. Mazerski J., Statystyczna analiza wyników doświadczalnych [Statistical analysis of experimental results], Wydawnictwo MALAMUT, Warszawa 2009 (in Polish)

14. PN-B-04452_2002 Geotechnika. Badania polowe [Geotechnics. Field testing]. 2002 (in Polish)

15. Haponiuk B., Zbiciak A., Mechanistic-empirical asphalt pavement design considering the effect of seasonal temperature variations, Archives of Civil Engineering 62.4: 35-50, 2016.

16. Nagórski R., Tutka P., Złotowska M., Defining the domain and boundary conditions for finite element model of flexible road pavement, Roads and Bridges-Drogi i Mosty 16.4: 265-277, 2017.

17. Superczyńska M., Józefiak K., Zbiciak A., Numerical analysis of diaphragm wall model executed in Poznań clay formation applying selected FEM codes, Archives of Civil Engineering 62.3: 207-224, 2016.

\section{LIST OF FIGURES AND TABLES:}

Fig. 1. Example geological transect in the area of research

Rys. 1 Przykład przekroju geologicznego w obszarze prowadzenia badań

Fig. 2. CPTU test rig and Panda 2 prepared for testing

Rys. 2. OPrzygotowane do badań oprzyrządowanie penetrometru PANDA 2 oraz sondy CPTU

Fig. 3. Schematic layout of the test points 
Rys. 3. Schematyczny plan sondowań

Fig. 4. Panda 2 test rig prepared for testing

Rys. 5. Osprzęt penetrometru PANDA 2 przed badaniem

Fig. 5. Schematic of PANDA 2 operation. [9]

Rys. 5. Opis zasady działania PANDA 2

Fig. 6. Example readouts recorded by the data acquisition unit (from the top: energy given to the system with each blow, cone resistance and cone penetration) and example chart of complete test carried out with PANDA 2 system.

Rys. 6. Przykładowe odczyty z urządzenia (patrząc od góry: energia uderzenia, opór na stożku, zagłębienie stożka) oraz przykładowy wykres z badania przeprowadzonego z wykorzystaniem urządzenia PANDA 2

Fig. 7. Cone resistances obtained with different probes, depending on the penetration depth (test point No. 11)

Rys. 7. Przykładowy wynik porównania oporów zmierzonych na stożkach różnych sond (pomiar w punkcie 11)

Fig. 8. Cone resistances obtained with different probes, depending on the penetration depth (test point No. 2)

Rys. 8. Przykładowy wynik porównania oporów zmierzonych na stożkach różnych sond (pomiar w punkcie 2)

Fig. 9. Relationship between resistances obtained with different test rigs

Rys. 9. Zależność między oporami uzyskanymi z różnych urządzeń

Fig. 10. Residuals chart of a linear correlation function

Rys. 10. Wykres reszt w przypadku korelacji liniowej

Fig. 11. Relationship between resistances obtained with different test rigs in the log-log plane

Rys. 11. Zależność między oporami uzyskanymi z różnych urządzeń na płaszczyźnie logarytmicznej

Fig. 12. Residuals chart of the logarithmic correlation function

Rys. 12. Wykres reszt w przypadku korelacji na płaszczyźnie logarytmicznej

Fig. 13. Relationship between cone resistances obtained with different test rigs (dotted line - mean, continuous line - confidence interval)

Rys. 13. Zależność między oporami na stożkach różnych sond - z naniesionymi przedziałami ufności 


\section{VALIDATION OF THE CONE PENETROMETER SUITABILITY FOR THE SOIL STATE DETERMINING ON THE BASIS OF A COMPARISON WITH THE RESULTS OF THE STATIC PROBE CPT}

Keywords: conical penetrometer, static probe CPT, in-situ methods, soil condition, correlation

\section{SUMMARY}

The article presents an assessment of the suitability of the cone penetrometer to determine the soil state. The work describes the principle of the device operation, which is similar to commonly used dynamic DPL probes. Then, the results of research conducted in Polish conditions using the new conical penetrometer were presented. A series of measurements were performed in real field conditions. On their basis, an attempt was made to correlate the results obtained with a conical penetrometer and a static probe CPT. Then, the obtained correlations were validated. On this basis preliminary evaluation of the conical penetrometer suitability for the soil state determining.

\section{WALIDACJA PRZYDATNOŚCI PENETROMETRU STOŻKOWEGO DO OKREŚLENIA STANU GRUNTU NA PODSTAWIE PORÓWNANIA Z WYNIKAMI SONDY STATYCZNEJ CPT}

Slowa kluczowe: penetrometr stożkowy, sonda statyczna CPT, metody in-situ, stan gruntu, korelacja,

\section{STRESZCZENIE}

Artykuł przedstawia ocenę przydatności penetrometru stożkowego do określenia stanu gruntu. W pracy opisano zasadę działania urządzenia, podobną do powszechnie stosowanych sond dynamicznych typu DPL. Następnie przedstawiono wyniki badań przeprowadzonych w warunkach polskich z wykorzystaniem nowego penetrometru stożkowego. Szereg pomiarów wykonano w realnych warunkach terenowych. Na ich podstawie podjęto próbę korelacji wyników uzyskanych penetrometrem stożkowym oraz sondą statyczną CPT. Następnie uzyskane korelacje poddano walidacji i na tej podstawie wstępnie oceniono przydatność zastosowania penetrometru stożkowego do określenia stanu gruntu. 